\title{
HUBUNGAN KEBIASAAN SARAPAN PAGI DENGAN KEJADIAN ANEMIA PADA MAHASISWA
}

\author{
Lilis Banowati*Jongga Adiyaksa**
}

\begin{abstract}
ABSTRAK
Anemia merupakan masalah kesehatan masyarakat global di negara berkembang maupun negara maju dengan konsekuensi yang besar bagi kesehatan manusia serta pembangunan nasional dan ekonomi. Anemia pada remaja akibat kurang gizi dapat berdampak buruk pada kesehatan, pertumbuhan, dan sistem imun. Penyebab utama anemia gizi ialah konsumsi zat besi yang tidak cukup, absorbsi zat besi yang rendah, dan pola makan yang sebagian besar terdiri dari nasi dan menu yang kurang beraneka ragam. Kebiasaan makan pagi termasuk dalam salah satu dari 13 pesan dasar gizi seimbang. Bagi mahasiswa/remaja, makan pagi dapat meningkatkan konsentrasi belajar dan memudahkan menyerap pelajaran yang akan meningkatkan prestasi belajar. Makan pagi juga sangat berperan terhadap pemenuhan gizi seimbang pada anak. Tujuan penelitian ini untuk mengetahui hubungan antara kebiasaan makan pagi dengan kejadian anemia pada mahasiswa program studi D III Gizi Cirebon Poltekkes Kemenkes Tasikmalaya.

Penelitian ini merupakan penelitian observational dengan menggunakan desain cross-sectional. Populasi pada penelitian ini adalah mahasiswa Prodi D III Gizi Cirebon Poltekkes Kemenkes Tasikmalaya dengan jumlah 122 orang. Teknik pengambilan sampel menggunakan teknik random sampling yaitu sejumlah 35 orang.

Hasil penelitian menunjukkan bahwa dari 35 mahasiswa, 29 mahasiswa memiliki kebiasaan makan pagi 29 mahasiswa (83\%) yang tidak anemia, jarang sarapan pagi yaitu 1 mahasiswa $(2,8 \%)$ dan yang tidak pernah sarapan yaitu 5 mahasiswa. Nilai pValue dari uji Chi square yaitu $0,125(\mathrm{P}<0,05)$. Sehingga hasilnya yaitu ada hubungan kebiasaan sarapan pagi dengan kejadian anemia pada mahasiswa
\end{abstract}

Kata kunci: kebiasaan makan pagi, anemia, mahasiswa

\begin{abstract}
Anemia is a global public health problem in both developing and developed countries with great consequences for human health as well as national and economic development. Anemia in adolescents due to malnutrition can adversely affect health, growth, and the immune system. The main causes of nutritional anemia are insufficient intake of iron, low iron absorption, and a diet consisting mostly of rice and a less varied menu. Breakfast habits are included in one of 13 basic messages of balanced nutrition. For students, breakfast can increase the concentration of learning and make it easier to absorb lessons that will improve learning achievement. Breakfast also greatly contribute to the fulfillment of balanced nutrition in children. The purpose of this study to determine the relationship between morning eating habits with the incidence of anemia in the students of study program D III Gizi Cirebon Poltekkes Kemenkes Tasikmalaya.

This research is an observational research using cross-sectional design. The population in this study is a student of Study Program D III Gizi Cirebon Poltekkes Kemenkes Tasikmalaya with the number of 122 people. Sampling technique using random sampling technique that is a number of 35 people.

The result of the research shows that from 35 students, 29 students have breakfast habit of 29 students (83\%) who are not anemic, rarely breakfast that is 1 student $(2.8 \%)$ and who never breakfast is 5 students. The pValue value of Chi square test is $0,125(\mathrm{P}<0,05)$. So the result is a relationship between breakfast habits with the incidence of anemia in students
\end{abstract}

Keywords: breakfast habits, anemia, students

\footnotetext{
* Staf Pengajar PSKM STIKes Cirebon

**Mahasiswa PSKM STIKes Cirebon
} 


\section{PENDAHULUAN}

Kualitas sumber daya manusia (SDM) ditentukan oleh banyak faktor yang saling berhubungan, berkaitan, dan saling bergantung, diantaranya adalah faktor pendidikan dan kesehatan. Kesehatan merupakan prasyarat yang diperlukan agar upaya pendidikan berhasil, selanjutnya pendidikan yang diperoleh akan sangat mendukung tercapainya peningkatan status kesehatan seseorang. Untuk membentuk kualitas manusia yang mempunyai kemampuan kerja fisik yang baik, tentunya harus didukung oleh tingkat keadaan gizi yang baik pula. Keadaan gizi yang baik akan meningkatkan kualitas hidup seseorang; kualitas hidup yang tinggi akan mendukung hasil kerja yang efisien dan optimal. Sebaliknya keadaan gizi yang tidak baik akan menurunkan daya tahan tubuh terhadap penyakit infeksi serta produktivitas kerja yang rendah. Keadaan gizi yang tidak baik seperti kekurangan zat gizi mikro masih merupakan masalah di Negara berkembang. ${ }^{1}$

Defisiensi zat besi merupakan defisiensi zat gizi mikro yang paling umum terjadi di dunia dan merupakan masalah gizi kurang yang banyak diderita oleh remaja. ${ }^{2}$ Defisiensi zat besi merupakan hasil jangka panjang dari keseimbangan negatif zat besi dan tingkatan yang paling parah dari defisiensi zat besi disebut dengan anemia. ${ }^{3}$ Menurut Soekirman, saat ini diperkirakan lebih kurang 2,1 milyar orang di dunia menderita anemia gizi besi termasuk pada tingkat berat dan pada negara berkembang terdapat prevalensi anemia pada remaja putri sebesar 17-89 persen. Hasil SKRT 2001 menunjukkan bahwa 30 persen remaja wanita (10-19 tahun) menderita anemia (konsentrasi hemoglobin $<120 \mathrm{~g} / \mathrm{l}$ ). Hasil tersebut tidak jauh berbeda dari hasil studi lainnya, yang mengindikasikan anemia merupakan masalah kesehatan di Indonesia. $^{3}$

Remaja putri memiliki risiko sepuluh kali lebih besar untuk menderita anemia dibandingkan dengan remaja putra. Hal ini dikarenakan remaja putri mengalami menstruasi setiap bulannya dan sedang dalam masa pertumbuhan sehingga membutuhkan asupan zat besi yang lebih banyak. Selain itu, ketidakseimbangan asupan zat gizi juga menjadi penyebab anemia pada remaja. Remaja putri biasanya sangat memperhatikan bentuk tubuh, sehingga banyak yang membatasi konsumsi makanan dan banyak pantangan terhadap makanan. ${ }^{4}$ Bila asupan makanan kurang maka cadangan besi banyak yang dibongkar. Keadaan seperti ini dapat mempercepat terjadinya anemia. ${ }^{5}$

Sarapan pagi merupakan makanan yang dimakan setiap pagi hari atau suatu kegiatan yang penting dilakukan sebelum mengisi aktivitas yang lain setiap hari. Sarapan dibutuhkan untuk mengisi lambung yang telah kosong selama 8-10 jam dan bermanfaat dalam meningkatkan kemampuan konsentrasi belajar dan kemampuan fisik. Oleh karena itu untuk meningkatkan konsentrasi belajar dan kemampuan fisik pada saat sarapan pagi harus diperhatikan pemilihan menu serta kandungan gizi yang baik untuk pemenuhan zat-zat gizi pada pagi hari.

Hasil studi faktor risiko lainnya menunjukkan bahwa terdapat faktor-faktor lain yang berpengaruh terhadap kejadian anemia antara lain pendidikan, jenis kelamin, wilayah, kebiasaan sarapan, status kesehatan, dan keadaan Indeks Massa Tubuh (IMT) dalam kategori kurus. ${ }^{6}$ Sedangkan menurut hasil penelitian Maharani, faktor risiko yang secara signifikan mempengaruhi kecenderungan status anemia mahasiswa baru yaitu faktor jenis kelamin, umur, pendapatan orang tua, dan status proteinuria. Adanya faktor risiko tersebut dapat mempengaruhi kecenderungan status anemia seseorang terutama pada remaja yang berada dalam masa pertumbuhan.

Faktor lainnya yang mempengaruhi Anemia adalah sarapan. Sarapan termasuk ke dalam salah satu Tiga Belas Pesan Umum Gizi Seimbang (PUGS). Bagi anak sekolah, makan pagi dapat mempengaruhi kadar $\mathrm{Hb}$ dan memudahkan menyerap pelajaran sehingga meningkatkan prestasi belajar. Banyak penelitian yang mengungkapkan bahwa sarapan berhubungan dengan konsentrasi bahwa anak yang biasa sarapan pagi mempunyai konsentrasi 
yang lebih tinggi dibandingkan anak yang tidak sarapan pagi. Lalu penelitian yang dilakukan oleh Saidin pada anak sekolah dasar di pedesaan di wilayah Kabupaten Bogor menyimpulkan bahwa kebiasaan tidak sarapan berpengaruh pada konsentrasi anak. ${ }^{5}$

Kejadian anemia banyak terjadi karena rendahnya kadar hemoglobin dalam darah. Salah satu penyebab rendahnya kadar hemoglobin dalam darah karena asupan makan yang tidak menyukupi. Asupan zat gizi sehari-hari sangat dipengaruhi oleh kebiasaan makan pagi. Rendahnya kadar hemoglobin disebabkan karena masukan (intake) makanan yang tidak memenuhi kebutuhan, sehingga menyebabkan kurangnya cadangan zat gizi besi dalam tubuh. Hasil penelitian yang dilakukan di sekolahan swasta yang ada di Jeddah Arab Saudi, anemia lebih umum di kalangan anak sekolah yang melewatkan makan pagi atau tidak makan sayuran hijau dan buah-buahan. Hasil dari penelitian Palup (2011) tentang kebiasaan makan pagi pada siswa sekolah dasar di Kabupaten Sukoharjo yang dilakukan di SD Negeri Trangasan Kecamatan Gatak, menunjukan bahwa sebagian besar siswa yaitu 67,6\% memiliki kebiasaan makan pagi yang baik dan sisanya $32,4 \%$ tidak memiliki kebiasan makan pagi yang baik. ${ }^{6}$ Tandirerung, dkk (2013) dalam penelitiannya yang dilakukan di SD Negeri 3 Manado menyimpulkan bahwa terdapat hubungan yang bermakna antara kebiasaan makan pagi dengan kejadian anemia $(p=0,019)^{7}$

Berdasarkan beberapa kejadian pada mahasiswa prodi D III Gizi Cirebon pada tahun 2015, terdapat 5 orang mahasiswa Prodi D III Gizi Cirebon yang sering mengalami lemas, pusing bahkan pingsan dan beberapa diantaranya tidak pernah sarapan. Setelah dilakukan pemeriksaan $\mathrm{Hb}, 2$ orang mahasiswa diantaranya kadar Hb kurang dari $11 \mathrm{gr} / \mathrm{dl}$. Mengingat dampak yang terjadi akibat anemia sangat merugikan kualitas kerja dan mutu sumber daya manusia di masa mendatang, serta konsentrasi pada saat proses belajar mengajar, maka peneliti tertarik untuk mengetahui hubungan kebiasaan sarapan dengan kejadian anemia pada mahasiswa Prodi D III Gizi Poltekkes Kemenkes Tasikmalaya. Tujuan penelitian ini adalah mengetahui hubungan kebiasaan sarapan dengan kejadian anemia pada mahasiswa Program Studi D III Gizi Poltekkes Kemenkes Tasikmalaya

\section{METODE PENELITIAN}

Rancangan penelitian yang digunakan adalah studi observational dengan menggunakan desain cross-sectional. Variabel bebas pada penelitian adalah kebiasaan sarapan. Variabel terikat pada penelitian kejadian Anemia Mahasiswa Prodi D III Gizi Poltekkes Kemenkes Tasikmalaya. Populasi pada penelitian ini adalah mahasiswa Prodi D III Gizi Cirebon Poltekkes Kemenkes Tasikmalaya dengan jumlah 122 orang. Teknik pengambilan sampel menggunakan teknik random sampling yaitu sejumlah 35 orang. Jenis data yang dikumpulkan adalah data primer. Data primer merupakan data yang diambil langsung didapatkan dari responden dengan pengisian kuesioner tentang sarapan pagi dan pengambilan darah dan pengukuran kadar hemoglobin. Analisis univariat dilakukan dengan membuat tabulasi frekuensi. Analisis bivariat untuk mengetahui hubungan antara kebiasaan sarapan pagi dengan prevalensi anemia pada mahasiswa Prodi D III Gizi Poltekkes Kemenkes Tasikmalaya dengan menggunakan uji Chi Square. Untuk melihat adanya hubungan dilakukan dengan membandingkan $p$ value dan $\alpha=0,05$, jika $\mathrm{p}$ value $<0,05$ maka dapat disimpulkan adanya hubungan.

\section{HASIL PENELITIAN Kebiasaan Sarapan}

Tabel 1 menunjukkan bahwa sebagian besar responden selalu membiasakan kebiasaan sarapan pagi yaitu sebanyak 29 responden $(83 \%)$. 
Tabel 1. Distribusi Kebiasaan Sarapan Responden

\begin{tabular}{ccc}
\hline Kebiasaan sarapan & $\mathrm{n}$ & Persentase (\%) \\
\hline Tidak pernah & 5 & 14,2 \\
Jarang & 1 & 2,8 \\
Selalu & 29 & 83 \\
\hline Total & 35 & 100 \\
\hline
\end{tabular}

\section{Kadar Hemoglobin $(\mathrm{Hb})$}

Gambaran $\mathrm{Hb}$ responden diperoleh dari pengambilan sampel darah perifer yang dilakukan dalam satu waktu dan di baca pada spektrofotometer. Berikut adalah gambaran $\mathrm{Hb}$ pada responden :

Tabel 2. Gambaran $\mathrm{Hb}$ berdasarkan jenis kelamin pada responden

\begin{tabular}{cccc}
\hline Jenis Kelamin & Hemoglobin $(\mathrm{Hb})$ & $\mathrm{N}$ & Persentase $(\%)$ \\
\hline Laki-laki & $<11,9 \mathrm{gr} / \mathrm{dL}$ & 3 & 8,6 \\
& $\geq 12 \mathrm{gr} / \mathrm{dL}$ & 0 & 0 \\
\hline Perempuan & $<11,9 \mathrm{gr} / \mathrm{dL}$ & 6 & 17,1 \\
& $\geq 12 \mathrm{gr} / \mathrm{dL}$ & 26 & 74,3 \\
\hline & Jumlah & 35 & 100 \\
\hline
\end{tabular}

Berdasarkan tabel 2 menunjukkan bahwa responden dengan jenis kelamin laki-laki memiliki kadar $\mathrm{Hb} \geq 12 \mathrm{gr} / \mathrm{dl}$ sebanyak 3 orang, jenis kelamin perempuan yang memiliki kadar $\mathrm{Hb}<11,9 \mathrm{gr} / \mathrm{dL}$ sebanyak 6 orang dan perempuan yang memiliki kadar $\mathrm{Hb} \geq 12$ sebanyak 26 orang

Tabel 3. Tabel Kejadian Anemia

\begin{tabular}{ccc}
\hline Status Anemia & N & Persentase $(\%)$ \\
\hline Normal $(\geq 12$ gr/dL) & 29 & 82,16 \\
Anemia Ringan $(<11,9 \mathrm{gr} / \mathrm{dL})$ & 6 & 17,14 \\
\hline Jumlah & 35 & 100 \\
\hline
\end{tabular}

Berdasarkan tabel 3 menunjukkan bahwa kejadian anemia pada mahasiswa Prodi D III gizi Cirebon sebesar 17,14 \% dan yang normal sebesar 82,16 \%. Angka kejadian anemia pada mahasiswa prodi D III Gizi Cirebon terjadi pada mahasiswa yang jarang sarapan pagi dan tidak pernah sarapan pagi.

\section{Hubungan Kebiasaan Sarapan Pagi dengan Kejadian Anemia}

Tabel 4. Tabel Hubungan kebiasaan sarapan pagi dengan kejadian anemia

\begin{tabular}{|c|c|c|c|c|c|c|c|}
\hline \multirow{3}{*}{$\begin{array}{c}\text { Kebiasaan } \\
\text { Sarapan }\end{array}$} & \multicolumn{4}{|c|}{ Status Anemia } & \multirow{2}{*}{\multicolumn{2}{|c|}{ Total }} & \multirow[t]{3}{*}{$\mathrm{P}$ value } \\
\hline & \multicolumn{2}{|c|}{ Normal } & \multicolumn{2}{|c|}{ Anemia Ringan } & & & \\
\hline & $\mathrm{n}$ & $\%$ & $\mathrm{n}$ & $\%$ & $\mathrm{n}$ & $\%$ & \\
\hline Tidak pernah & 0 & 0 & 5 & 100 & 5 & 100 & 0,125 \\
\hline Jarang & 0 & 0 & 1 & 100 & 1 & 100 & \\
\hline Selalu & 29 & 100 & 0 & 0 & 29 & 100 & \\
\hline
\end{tabular}

Tabel 4 menunjukkan bahwa responden yang tidak pernah sarapan pagi memiliki kadar $\mathrm{Hb}<11,9 \mathrm{gr} / \mathrm{dL}$ dan mengalami anemia ringan sebanyak 5 orang, responden yang jarang sarapan pagi memiliki kadar $\mathrm{Hb}<11,9 \mathrm{gr} / \mathrm{dL}$ dan mengalami anemia ringan sebanyak 1 orang, serta yang selalu sarapan pagi memiliki kadar $\mathrm{Hb}>12 \mathrm{gr} / \mathrm{dL}$ dan tidak mengalami 
anemia/normal sebanyak 29 orang. Dari hasil analisis dengan uji Chi-square, nilai pvalue yaitu $0,125(\mathrm{P}<0,05)$. Sehingga ada hubungan kebiasaan sarapan dengan kejadian anemia pada mahasiswa prodi D III Gizi Cirebon.

\section{PEMBAHASAN}

\section{Kebiasaan Sarapan}

Kebiasaan sarapan pagi pada mahasiswa prodi D III Gizi Cirebon hampir sebagian besar melakukan sarapan pagi. Usia Responden berkisar 18-21 tahun. Hasil penelitian menunjukkan bahwa yang tidak sarapan pagi sebesar $14,2 \%$,reponden yang jarang sarapan pagi sebesar 2,8\% dan yang selalu sarapan pagi sebesar $83 \%$.

Sarapan menjadi perilaku yang baik apabila dilakukan secara rutin atau menjadi kebiasaan. Seseorang yang biasa sarapan dapat dikatakan mempunyai kebiasaan yang baik terutama dalam memenuhi kebutuhan energinya. Kebiasaan sarapan terutama pada mahasiswa sangat dipengaruhi oleh perilaku dalam membiasakan sarapan di pagi hari.

Sarapan dikatakan berkualitas baik apabila jenis makanan yang konsumsi mengandung nutrisi yang dibutuhkan pada masa remaja menyebutkan menu sarapan pagi sebaiknya lengkap dan mengandung semua unsur gizi yang dibutuhkan tubuh, karena sangat menentukan stamina tubuh pada siang hari. Menu sarapan yang cukup mengandung protein, vitamin, zat besi dan lemak yang mengandung omega 3 akan memberikan nutrisi yang baik untuk perkembangan remaja.

Mahasiswa sebagai bagian dari masyarakat Indonesia dan khususnya sebagai generasi penerus bangsa diharapkan memiliki perilaku hidup sehat. Aktivitas yang padat serta kehidupan sosial pada mahasiswa sangat mempengaruhi perilaku hidup sehatnya khususnya pola makannya sehari-hari seperti makan yang tidak teratur, tidak sarapan pagi atau bahkan tidak makan siang serta sering mengonsumsi jajanan

Berdasarkan hasil survey yang dilakukan oleh Darlina, $89 \%$ mahasiswa putri dan $92 \%$ mahasiswa putra suka mengonsumsi mie instant sebagai makanan pengganti pada saat-saat tertentu seperti waktu pagi dan malam hari. Sebagian mahasiswa USU memberi alasan mengonsumsi mie instant karena harga yang relatif murah dibandingkan dengan membeli sebungkus nasi. Kebiasaan mengonsumsi mie instant tersebut dapat menimbulkan masalah gizi, mengingat mie instant termasuk makanan yang mengenyangkan dan cepat menimbulkan rasa puas sehingga dapat mengakibatkan kekurangan gizi apabila tidak ditambahkan lauk pauk untuk melengkapi gizinya. ${ }^{8}$

\section{Kejadian Anemia}

Berdasarkan hasil penelitian yang dilakukan oleh penulis, tingkat kejadian anemia pada mahasiswa Program Studi D III Gizi Cirebon dari 35 responden terdapat 6 kejadian anemia dalam kategori anemia ringan dengan persentase sebesar $17,14 \%$. Hal ini terjadi pada mahasiswa yang jarang sarapan pagi dan tidak pernah sarapan pagi. Kejadian anemia berdasarkan jenis kelamin dialami rata-rata oleh perempuan. Responden perempuan yang mengalami anemia ringan pada saat penelitian dilakukan tidak sedang dalam keaadaan menstruasi. Hal ini menunjukkan bahwa kejadian anemia yang terjadi pada mahasiswa Prodi D III gizi Cirebon bias dipengaruhi oleh kebiasaan sarapan

Masa remaja merupakan masa dimana mengalami pertumbuhan yang pesat, perubahan psikologis yang dramatis serta peningkatan aktivitas yang menjadi karakteristik masa remaja, menyebabkan peningkatan kebutuhan zat gizi, dan terpenuhi atau tidak terpenuhinya kebutuhan ini akan mempengaruhi status gizi. Meningkatnya aktivitas, kehidupan sosial, dan kesibukan pada remaja, akan mempengaruhi kebiasaan makan mereka. Pola konsumsi makanan sering tidak teratur, sering jajan, sering tidak makan pagi, dan sama sekali tidak makan siang. ${ }^{9}$ 
Terutama pada remaja putri, mereka lebih memperhatikan penampilan dirinya, seringkali terlalu ketat dalam pengaturan pola makannya karena enggan menjadi gemuk, sehingga dapat mengakibatkan kekurangan zat gizi. ${ }^{9}$ Jumlah waktu makan yang ditunda dan makan diluarrumah meningkat mulai awal remaja sampai remaja akhir. Terdapat peningkatan asupan makanan siap saji yang cenderung mengandung lemak, kalori, natrium tingi, dan rendah asam folat, serat, dan vitamin $\mathrm{A}$.

Terdapat beberapa faktor yang mempengaruhi pola makan pada remaja, yaitu pola makan keluarga, teman sebaya, dan media. ${ }^{10}$ Remaja yang sering makan bersama dengan keluarganya memiliki pola makan lebih baik dengan makanan yang lebih sehat dibandingkan dengan mereka yang jarang makan bersama dengan keluarga. ${ }^{11}$ Remaja dengan aktivitas sosial tinggi,memperlihatkan peran teman sebaya menjadi tampak jelas. Di kota besar sering kita lihat kelompok-kelompok remaja bersama-sama makan dirumah makan yang menyajikan makanan siap saji (fast food). Masa remaja merupakan target utama iklan restoran cepat saji, makanan ringan, dan minuman manis, yang akan mempengaruhi pilihan makanan. Dengan kemudahan akses terhadap media, akan memiliki pengaruh jangka panjang terhadap pilihan makanan dan menghasilkan kebiasaan makan yang buruk pada remaja. ${ }^{12}$

Apabila sejak remaja seorang wanita menderita anemia, maka akan mengakibatkan pertumbuhan dan perkembangan terganggu, lemah karena sering terkena infeksi, tidak aktif, malas, cepat lelah, di sekolah sulit berkonsentrasi dalam belajar, mengantuk, akibat lebih lanjutnya akan mempengaruhi kecerdasan dan daya tangkap anak. ${ }^{13}$ Selain itu, akan semakin berat kondisinya bila wanita tersebut menikah dan hamil, karena kehamilan membutuhkan lebih banyak jumlah zat besi untuk pertumbuhan dan perkembangan janinnya, maka akan berdampak pada kematian bayi, bayi lahir abnormal, kematian premature, berat badan bayi lahir rendah, dan kematian ibu. ${ }^{14}$

\section{Hubungan Kebiasaan sarapan dengan Kejadian Anemia}

Makan/sarapan pagi yaitu : makanan yang dimakan sebelum beraktifitas, yang terdiri dari makanan pokok dan lauk pauk atau makanan kudapan. Jumlah yang dimakan kurang lebih 1/3 dari makanan sehari. Sedangkan menurut Depkes sarapan adalah mengkonsumsi makanan yang dimakan pada waktu pagi hari sebelum berangkat atau melakukan kegiatan disekolah. ${ }^{15}$

Hasil analisis dengan menggunakan uji Chi-square, nilai pvalue dari penelitian ini yaitu $0,125(\mathrm{P}<1)$. Sehingga hasilnya yaitu ada hubungan kebiasaan sarapan pagi dengan kejadian anemia pada mahasiswa Program Studi D III Gizi Cirebon.

Hasil penelitian ini sesuai dengan penelitian Chusniaty terdapat hubungan yang signifikan antara kebiasaan sarapan pagi setiap hari dengan kejadian anemia, yang mana remaja putri yang tidak mempunyai kebiasaan sarapan pagi setiap hari memiliki risiko 3,421 kali menderita anemia dibandingkan dengan remaja putri yang mempunyai kebiasaan sarapan pagi setiap hari. ${ }^{16}$ Berdasarkan penelitian Permaesih didapatkan hasil bahwa remaja putri yang tidak terbiasa sarapan pagi setiap hari memiliki resiko menderita anemia 1,6 kali dibandingkan dengan remaja putri yang mempunyai kebiasaan sarapan pagi setiap hari. ${ }^{17}$ Penelitian Wijiastuti pada remaja putri Madrasah Tsanawiyah Negeri Cipondoh Tangerang juga mendapatkan hubungan yang bermakna antara sarapan pagi dengan kejadian anemia, yang mana remaja putri yang tidak terbiasa sarapan pagi setiap hari memiliki resiko menderita anemia 4,88 kali dibandingkan dengan remaja putri yang mempunyai kebiasaan sarapan pagi setiap hari. ${ }^{18}$

Kebiasaan makan menurut Khumaidi adalah tingkah laku manusia atau kelompok manusia dalam memenuhi kebutuhannya akan makan yang meliputi sikap, kepercayaan, dan pemilihan terhadap makanan. Sikap seseorang terhadap makanan dapat bersifat positif atau negatif, kepercayaan orang terhadap makanan berkaitan dengan nilai baik atau buruk, menarik 
atau menarik. Sedangkan pemilihan makanan berdasarkan sikap dan kepercayaan. ${ }^{19}$ Kebiasaan makan meliputi :

1. Sikap terhadap makanan Adalah kecenderungan bertingkah laku terhadap makanan yang didalamnya terkandung unsur suka atau tidak suka terhadap makanan.

2. Kepercayaan terhadap makanan pantangan. Kecenderungan terhadap makanan pantangan, diterima atau tidak untuk dilakukan, biasanya berkaitan dengan nilai-nilai budaya dan agama.

3. Pemilihan makanan. Macam makanan yang biasa dikonsumsi dalam sehari meliputi susunan menu dan porsi untuk sarapan pagi, frekuensi sarapan pagi atau tingkat keseringan sarapan pagi berdasarkan sikap dan kepercayaan terhadap suatu makanan pantangan.

\section{SIMPULAN}

1. Mahasiswa yang tidak pernah sarapan pagi sebanyak 5 orang $(14,2 \%)$, mahasiswa yang jarang sarapan pagi sebanyak $(2,8 \%)$ dan mahasiswa yang selalu sarapan pagi sebanyak $(83 \%)$

2. Kadar hemoglobin berdasarkan jenis kelamin yaitu laki-laki sebanyak 3 orang ( $>12 \mathrm{gr} / \mathrm{dl}$ ) dan perempuan yang memiliki kadar hemoglobin $<11,9$ gr/dl sebanyak 6 orang dan perempuan yang memiliki kadar hemoglobin $>12$ gr/dl sebanyak 26 orang

3. Kejadian anemia pada mahasiswa Prodi D III Gizi Cirebon sebanyak 6 orang $(17,14 \%)$ dari 35 orang responden.

4. Nilai pValue dari uji Chi square yaitu $0,125(\mathrm{P}<0,05)$. Sehingga hasilnya yaitu ada hubungan kebiasaan sarapan pagi dengan kejadian anemia pada mahasiswa

\section{SARAN}

1. Bagi Peneliti

Perlu diadakan penelitian lanjutan yang serupa, namun lebih dipantau perilaku sarapan pagi dalam jangka waktu tertentu agar diperoleh tingkat kebiasaan sarapan pagi. Kebiasaan sarapan pagi juga dikaitkan dengan konsentrasi belajar pada mahasiswa.

2. Bagi Prodi D III Gizi Cirebon

Bagi mahasiswa diharapkan agar lebih mengetahui pentingnya sarapan dan membiasakan perilaku sarapan pagi. Selain itu diharapkan pada penelitian ini mahasiswa dapat mempertahankan kebiasaan sarapan pagi dengan berbagai variasi menu.

\section{DAFTAR PUSTAKA}

1. Depkes. Rencana Pembangunan Kesehatan Menuju Indonesia Sehat 2010. [Diunduh tanggal 15 Januari 2016]. Tersedia dari : www.depkes.go.id. 2006

2. Ruel MT. Can Food-Based Strategies Help Reduce Vitamin A and Iron Deficiencies? A Review of Recent Evidence. Washington DC : International Food Policy Research Institute;2001

3. Soekirman. Ilmu Gizi dan Aplikasinya. Jakarta : DirJen PTDPN;2000.

4. WHO [World Health Organization]. Adolescent Nutrition: A Review of the Situation in Selected South-East Asian Countries. New Delhi : WHO Region Office for South-East Asia;2006

5. Permaesih D, S Herman. Faktor-faktor yang mempengaruhi anemia pada remaja. Buletin Penelitian Kesehatan 33(4):162-171.2005

6. Agus ZAN. Pengaruh Vitamin C Terhadap Absorpsi Zat Besi pada Ibu Hamil Penderita Anemia. In : MEDIKA Jurnal Kedokteran dan Farmasi. Vol. XXX; 2004.p. 496 - 499. 2010

7. Almatsier S. Prinsip Dasar Ilmu Gizi. Jakarta : PT. Gramedia Pustaka Utama;2001 
8. Darlina. Hubungan Konsumsi Mie Instant Dengan Status Gizi Pada Mahasiswa Di Asrama Putra. Medan: Universitas Sumatra Utara;2009

9. Sayogo, S. Gizi Dan Pertumbuhan Remaja. Jakarta: Fakultas Kedokteran Universitas Indonesia;2006

10. Arisman. Gizi Dalam Daur Kehidupan. Jakarta: EGC;2004

11. Arimurti, Ida. Makan Bersama Keluarga Membentuk Pola Makan Remaja Lebih Baik. 2009

12. Ayustaning Warno, Haryono. Tontonan Televisi Memmpengaruhi Pola Makan Remaja.2009

13. Wirakusumah. Perencanaan Menu Anemia Gizi Besi. Jakarta: PT Pustaka Pembangunan Swadaya Nusantara; 1999

14. Saraswati, E. Perbedaan Tingkat Pengetahuan Anemia Remaja Puteri SMU Anemia Dan Non Anemia Di Enam Dati II Provinsi Jabar. Bogor: Puslitbang Gizi;1997

15. Depkes. Survei Kesehatan Rumah Tangga. 2001

16. Chusniaty, N. Hubungan Anemia Dengan Karakteristik Responden, Pola Konsumsi Dan Asupan Zat Gizi Pada Remaja Puteri SMUN. Bekasi: Jurnal Gizi Klinik Indonesia;2002

17. Permaesih. Hubungan Antara Pengetahuan Dengan Perilaku Dalam Mencegah Anemia Gizi Besi Di SLTA 15 Jakarta Selatan. Skripsi. 2005

18. Wijiastuti, Harni. Faktor-faktor Yang Berhubungan Dengan Anemia Pada Remaja Puteri Di Tsanawiyah Negeri Cipondok Tangerang. Skripsi. Depok: Fakultas Kesehatan Masyarakat UI;2006

19. Khumaidi. Gizi Masyarakat. Jakarta: PT BPK Gunung Mulia;1994 